Research Article

\title{
Effect of surface roughness on the performance of heat exchanger
}

\author{
Ankur Geete $^{1} \cdot$ Rajendra Pathak ${ }^{1}$ \\ (c) Springer Nature Switzerland AG 2019
}

\begin{abstract}
In this research work, double-pipe counter flow heat exchanger has been analyzed with various roughnesses of steel, aluminum and copper pipes and also with two different cold fluids: water and ammonia at same flow rates. Dimensions of the heat exchanger are inner and outer diameters of inner pipe being 0.034 and $0.042 \mathrm{~m}$, whereas diameters of outer pipe are 0.054 and $0.06 \mathrm{~m}$, respectively, and length of heat exchanger is $1.8 \mathrm{~m}$. In K-E modeling, computational fluid dynamics tool has been used for performance analyses and this computational work has been validated by entropy, exergy and entransy analyses. After computational numerical analyses, this investigation has concluded that maximum rate of heat transfer through heat exchanger has been found with copper-ammonia combination with smooth surface. Minimum rates of entropy generation, exergy destruction, entransy dissipation-based thermal resistance and entransy dissipation number have been obtained with copper-water combination, and minimum entropy generation number and maximum effectiveness have been obtained with copper-ammonia combination. Percentage changes in the parameters/properties have also been calculated at different operating conditions. Copper as inner pipe material with smooth surface and ammonia as cold fluid have been recommended for counter flow double-pipe heat exchanger. Computer software has been developed for hassle-free analyses of heat exchanger.
\end{abstract}

Keywords Entropy analyses - Exergy analyses - Entransy analyses · Surface roughness · Double-pipe counter flow heat exchanger

\section{List of symbols}

$C_{p} \quad$ Specific heat of flowing fluids $(\mathrm{kJ} / \mathrm{kg}-\mathrm{K})$

$G \quad$ Entransy (kW-K)

$m$ Mass flow rate of fluid $(\mathrm{kg} / \mathrm{s})$

$T$ Temperature (K)

$S$ Entropy $(\mathrm{kW} / \mathrm{K})$

\section{Abbreviations}

d Dissipation

$f \quad$ Flowing fluid

Greek words

$\varphi_{\text {des }}$ Exergy destruction rate (kW)

$\varepsilon \quad$ Effectiveness

\section{Introduction}

In a heat exchanger, heat is transferred from hot fluid to cold fluid by conductive and convective heat transfer mechanisms. The hot or cold fluid is separated through solid walls called pipes to avoid mixing of fluid or direct contact. Shell- and tube-type heat exchanger, double-pipe heat exchanger and plate- or fin-type heat exchanger are different types of heat exchangers mainly used in various industries like power plants, chemical plants, refrigeration and air-conditioning systems [1-4]. Double-pipe counter flow heat exchanger (as shown in Fig. 1) has been chosen for CFD analyses and found effectiveness, overall heat transfer coefficient and outlet temperatures of the flowing fluids for different cases [5], and then numerical validation has been done by analyzing the rates of entropy generation, exergy destruction and entransy dissipation. The

$\triangle$ Ankur Geete, ankur_geete@yahoo.co.in | ${ }^{1}$ Mechanical Engineering Department, Sushila Devi Bansal College of Technology, Indore, Madhya Pradesh 453331, India.

SN Applied Sciences (2019) 1:901 | https://doi.org/10.1007/s42452-019-0954-x

Received: 4 May 2019 / Accepted: 19 July 2019 / Published online: 23 July 2019 


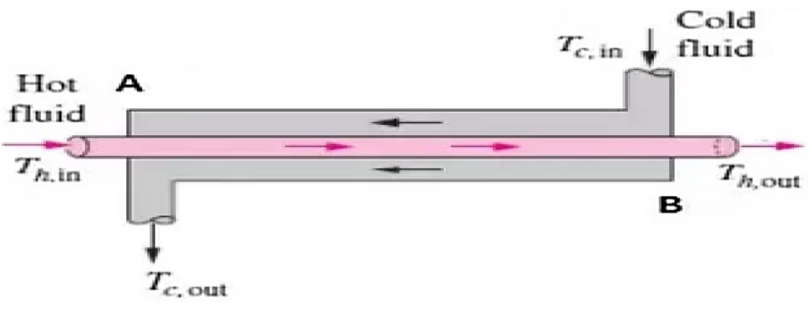

Fig. 1 Double-pipe counter flow heat exchanger

Table 1 Dimensions of double-pipe heat exchanger

\begin{tabular}{lllll}
\hline Sr. no. & Pipe & $\begin{array}{l}\text { Inner diam- } \\
\text { eter }(\mathrm{mm})\end{array}$ & $\begin{array}{l}\text { Outer diam- } \\
\text { eter }(\mathrm{mm})\end{array}$ & Length $(\mathrm{mm})$ \\
\hline 1 & Inner pipe & 34 & 42 & 1800 \\
2 & Outer pipe & 54 & 60 & 1800 \\
\hline
\end{tabular}

dimensions of double-pipe counter flow heat exchanger chosen in this research are shown in Table 1. Double-pipe counter flow heat exchanger has been analyzed with steel, aluminum and copper as inner pipe materials with water and ammonia as cold fluids. This work has been done with different roughnesses of pipes but same mass flow rates for hot and cold fluids, i.e., $0.08 \mathrm{~kg} / \mathrm{s}$.

Roughness which is extremely important for mechanical point of view is the component of surface texture and can be determined through deviations in normal vector's direction where large deviation indicates rough, whereas small deviation indicates smooth surfaces. High value of roughness is objectionable due to complexity in manufacturing, and manufacturing cost increases by decreasing the surface roughness. Surface roughness can be measured by surface roughness comparator manually, but generally it is measured by profilometer. Roughness is denoted by $\varepsilon_{r}$. There are two types of roughnesses: one is absolute roughness, and other is relative roughness. Absolute roughness is the measure of surface roughness of a material and this roughness is important for calculating pressure drop particularly in turbulent flow regime, but relative roughness is the ratio of roughness to diameter of pipe and it is used to measure the roughness of inner surface of the pipe. The value of friction factor can be found from moody chart by relative roughness [6]. If $\varepsilon_{r}$ is roughness of pipe $(\mathrm{mm})$ and $D$ is the diameter of pipe $(\mathrm{mm})$, then relative roughness can be expressed as:

Relative roughness $=\varepsilon_{r} / D$

Chen et al. have done work on entropy generation concepts on various thermodynamic systems; irreversible engine, pin fin heat sinks and also isothermal crystallization processes. After analyses, they suggested minimum entropy generation principle for better performance/ operation of thermodynamic systems [7-11]. Exergy analyses at different conditions have been performed on heat exchangers and power plants by Geete et al. and Ibrahim et al., and after analyses they found minimum exergy destruction is good for better outputs from thermal systems [12-16]. Chen et al., Feng et al., Guo et al. and other researchers have worked on entransy concepts for heat exchanging devices, and they applied entransy dissipation, entransy dissipation-based thermal resistance and entransy dissipation number on thermodynamic systems for comparative performance analyses and concluded that these parameters should be minimum [17-28]. In this research work, rates of entropy generation, exergy destruction, entransy dissipation, entransy dissipationbased thermal resistance, entransy dissipation numbers, effectiveness and entropy generation numbers have been calculated at different operating conditions to get better conditions at which performance of counter flow doublepipe heat exchanger will be the best.

\section{Methodology}

Outlet temperatures for double-pipe counter flow heat exchanger have been investigated with water and ammonia as cold fluids and steel, aluminum and copper as inner pipe materials at the different roughnesses of the inner surfaces of the inner pipes by CFD tools. In this research work, commercial code has been used for analyses in ANSYS Fluent 15.0 software. $K-\varepsilon$ modeling has been used for performance analyses and taken from the literature. It is well established fact that $\mathrm{K}-\varepsilon$ model has been used in RANS. For validation, rates of entropy generation, exergy destruction and entransy dissipation have been found with entransy dissipation-based thermal resistances, entropy generation numbers and entransy dissipation numbers for the same conditions, and the following methodology has been adopted for this research work. The first law of thermodynamics for cyclic process states that the cyclic integration of heat is equal to the cyclic integration of work, but when the first law is applied for a process, then a thermodynamic property comes out which is internal energy. Similarly, the second law of thermodynamics for cyclic process gives information about systems: heat engine, heat pump and refrigerator, but when this law is applied for a process, then a new property appears which is entropy (S). It has been found that for a closed system, change in entropy for irreversible process is more than the integration of $d Q / T$ for that process; it means some entropy is generated which indicates losses in the process. Internal irreversibility or dissipative work is the main cause for entropy generation, and it is always positive or zero (for 
reversible process). Irreversibility or losses can be calculated by entropy generation for heat exchangers, and it is calculated as [7-11]:

$T d S_{\text {gen }}=m_{h} C_{p h} \int\left(T_{h}\right)+m_{c} C_{p c} \int\left(T_{c}\right)$

$T d S_{\text {gen }}=m_{h} C_{p h} \int_{T h i}^{T h o} T h+m_{c} C_{p c} \int_{T c i}^{T c o} T_{c}$

$d S_{\text {gen }}=m_{h} C_{p h} \ln \left(T_{h o} / T_{h i}\right)+m_{c} C_{p c} \ln \left(T_{c o} / T_{c i}\right)$

where $d S_{\text {gen }}$ is the rate of entropy generation in $\mathrm{kW} / \mathrm{K}$. The exergy or available energy of a system can be defined as maximum possible work which is extracted from that system when system approaches the thermodynamic equilibrium state with its surrounding called dead state (i.e., $P_{a}$ and $T_{a}$ ). Exergy is that kind of property which depends on state of system and surrounding, and when system reaches dead state, exergy of system becomes zero. Reversible work transfer from the system is always greater than actual work transfer, and the difference between these works is known as irreversibility of the system; the term $T_{a} S_{\text {gen }}$ is the decrease in exergy of the system because of irreversibility. This concept was given by Gouy-Stodola, and he said the rate of exergy losses or exergy destruction rate in a process is proportional to the rate of entropy generation and ambient temperature. Exergy destruction rates for double-pipe counter flow heat exchanger have been calculated at various conditions by the following equation [12-16]:

$$
\begin{aligned}
0= & {\left[m_{h} C_{p h}\left\{\left(T_{h i}-T_{h o}\right)-T_{a} \ln \left(T_{h i}-T_{h o}\right)\right\}\right] } \\
& -\left[m_{c} C_{p c}\left\{\left(T_{c o}-T_{c i}\right)-T_{a} \ln \left(T_{c o}-T_{c i}\right)\right\}\right]-\varphi_{\text {des }}
\end{aligned}
$$

Exergy destruction rate $\left(\varphi_{\text {des }}\right)$

$$
\begin{aligned}
& =\left[m_{h} C_{p h}\left\{\left(T_{h i}-T_{h o}\right)-T_{a} \ln \left(T_{h i}-T_{h o}\right)\right\}\right] \\
& -\left[m_{c} C_{p c}\left\{\left(T_{c o}-T_{c i}\right)-T_{a} \ln \left(T_{c o}-T_{c i}\right)\right\}\right]
\end{aligned}
$$

where $m_{h}$ and $m_{c}$ are flow rates $(\mathrm{kg} / \mathrm{s}), C_{p h}$ and $C_{p c}$ are specific heats $(\mathrm{kJ} / \mathrm{kg}-\mathrm{K})$ of hot and cold fluids, respectively, $T_{h i}$ and $T_{c i}$ are inlet temperatures (Kelvin), $T_{h o}$ and $T_{c o}$ are outlet temperatures (Kelvin) of hot and cold fluids, $T_{a}$ is ambient temperature and $\varphi_{\text {des }}$ is exergy destruction rate (kW) [12-16]. The performance of heat exchanger can be analyzed by entransy which is the ability of heat transfer through heat exchanger, and it can be clarified by analogy between electrical and thermal parameters. If electrical and thermal potentials are $V$ and $T$, and electrical and heat fluxes are $I$ and $Q$, respectively, then electrical resistance will be $(V / I)$ and thermal resistance will be $(T / Q)$. Electricity and heat transfer rates are I and Q, Ohm's law is $I=K_{e} A$
(dV/dn), Fourier's law is $Q=K A(\mathrm{~d} T / \mathrm{d} n)$, electrical charge stored is $Q$, and heat stored is $Q(U)=m C_{v} T$. Electric capacitance is $Q N$, and thermal capacitance is $U / T$. Similarly, electrical potential energy stored in a capacitor is $Q V / 2$, and thermal potential energy stored in a system is UT/2. Thus, entransy $(G)$ is defined as the half of the product of internal energy $(U)$ and temperature $(T)$ and expressed as [17-27];

$G=1 / 2 U T$

Rate of entransy dissipation which is losses can be calculated by mass flow rates, specific heats and inlet/outlet temperatures of the hot and cold fluids, and it can be expressed as:

$G_{d}=1 / 2\left[m_{h} C_{p h}\left\{\left(T_{h i}\right)^{2}-\left(T_{h o}\right)^{2}\right\}\right]-1 / 2\left[m_{c} C_{p c}\left\{\left(T_{c o}\right)^{2}-\left(T_{c i}\right)^{2}\right\}\right.$

where $G$ is entransy ( $k W-K), G_{d}$ is rate of entransy dissipation (kW-K) and $U$ is internal energy $(\mathrm{kW})$. For performance analysis, entransy dissipation-based thermal resistance for heat exchanger is also found which is related to rate of entransy dissipation and heat transfer through heat exchanger and can be expressed as:

$R_{t}=G_{d} / Q^{2}$

where $R_{t}$ is entransy dissipation-based thermal resistance $(K / \mathrm{kW})$ and $Q$ is rate of heat transfer through heat exchanger (kW). A dimensionless number called entransy dissipation number is introduced by researchers for performance analysis of heat exchanger, and this term can be found by rate of entransy dissipation, heat transfer through heat exchanger and maximum temperature difference in heat exchanger (i.e., $T_{h i}$ and $T_{c i}$ ). Entransy dissipation number $(E D N)$ can be expressed as [28]:

$E D N=G_{d} /\left[Q\left(T_{h i}-T_{c i}\right)\right]$

This $E D N$ equation can be modified with effectiveness $(\varepsilon)$ which is the ratio of actual heat transfer $(Q)$ to maximum heat transfer $\left(Q_{\max }\right)$ through heat exchanger and can be written as [1-4];

$\varepsilon=(Q) /\left(Q_{\max }\right)$

$\varepsilon=\left[\left(m_{h} C_{p h}\right)_{\max }\left(T_{h i}-T_{h o}\right)\right] /\left[\left(m_{f} C_{p f}\right)_{\min }\left(T_{h i}-T_{c i}\right)\right]_{\max }$

or $\varepsilon=\left[\left(m_{c} C_{p c}\right)_{\max }\left(T_{c o}-T_{c i}\right)\right] /\left[\left(m_{f} C_{p f}\right)_{\min }\left(T_{h i}-T_{c i}\right)\right]_{\max }$

So, EDN can be modified as;

$E D N=G_{d} /\left[\varepsilon Q_{\max }\left(T_{h i}-T_{c i}\right)\right]$

$E D N=G_{d} /\left[\varepsilon\left\{\left(m_{f} C_{p f}\right)_{\min }\left(T_{h i}-T_{c i}\right)\right\}\left(T_{h i}-T_{c i}\right)\right]$

or $E D N=G_{d} /\left[\varepsilon\left(m_{f} C_{p f}\right)_{\min }\left(T_{h i}-T_{c i}\right)^{2}\right]$

In this research work, entropy generation number has been calculated for the heat exchanger and it should 
be as minimum as possible for the better performance of the heat exchanger. It is the ratio of entropy generation during irreversible heat transfer through the heat exchanger to the minimum heat capacity of the flowing fluid [29].

$N_{e g}=d S_{\text {gen }} /\left(m C_{p}\right)_{\min }$

In the present work, CFD analyses of double-pipe heat exchanger for counter flow have been performed where water is used as hot fluid while water or ammonia is used as cold fluids (which flow through heat exchanger) with steel, aluminum and copper as inner pipe materials with different roughnesses of pipes. After simulation, numerical validation has been done and compared all results and proved which pipe material (with surface roughness) and cold fluid give best effectiveness or rate of heat transfer but lowest rates of entropy generation, exergy and entransy dissipation and entransy dissipation number. Geometry of double-pipe heat exchanger is shown in Fig. 2, and four different meshes are given in Table 2 [5]. A method has been done to decide mesh for CFD analysis. For example, outlet temperatures of cold and hot fluids for mesh 3 and mesh 4 do not vary significantly (as in Table 2), so mesh 3 has been chosen for research work which has 485,831 elements and 507,656 nodes.

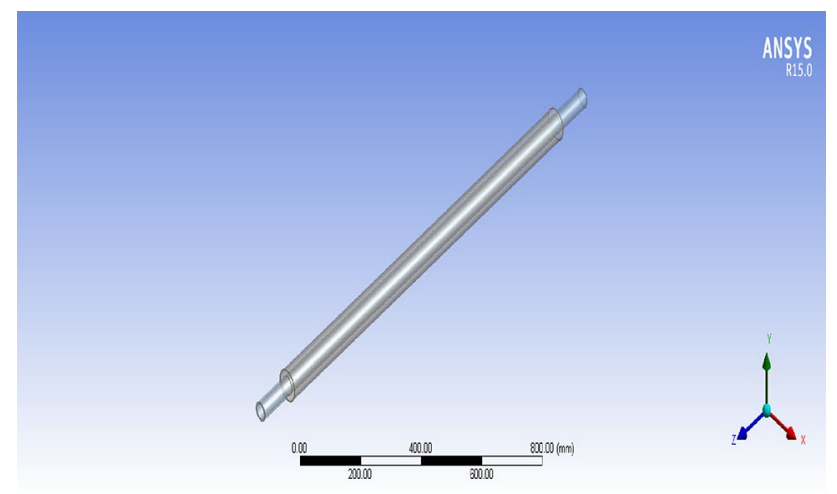

Fig. 2 Geometry of double-pipe counter flow heat exchanger

\section{Results}

Temperature counters have been found by CFD analyses at different operating conditions as shown in Figs. 3 and 4, and the conditions are: (a) inlet temperature of hot fluid (water) is $350 \mathrm{~K}$, inlet temperature of cold fluid (water) is $300 \mathrm{~K}$, mass flow rates of hot and cold fluids are $0.08 \mathrm{~kg} / \mathrm{s}$, specific heat of water is $4.186 \mathrm{~kJ} / \mathrm{kg}-\mathrm{K}$, inner pipe materials are steel, aluminum and copper, and outer pipe material is steel; and (b) inlet temperature of cold fluid (ammonia) is $210 \mathrm{~K}$, inlet temperature of hot fluid (water) is $300 \mathrm{~K}$, and specific heat of ammonia is $4.744 \mathrm{~kJ} / \mathrm{kg}-\mathrm{K}$. Results which have been obtained from CFD analyses for all three materials for all three cases of different cold fluids and roughnesses of inner pipes are mentioned in Tables 3, 4 and 5. Outlet temperatures and rates of heat transfer for each condition have been tabulated.

Results from analyses show that maximum heat transfer between hot and cold fluids can be achieved if thermal conductivity of the inner pipe of double-pipe heat exchanger is higher. Rate of heat transfer and effectiveness increases with the thermal conductivity of the material, and these parameters also change with the change in cold fluid and roughness of the pipe. Rates of entropy generation, exergy destruction and entransy dissipation with entransy dissipation-based thermal resistances, entransy dissipation numbers and entropy generation numbers are shown in Tables 6 and 7.

Comparative curves have also been plotted for different inner pipe materials and different roughnesses of pipes between the rates of heat transfer through heat exchanger, entropy generation, exergy destruction, entransy dissipation, entransy dissipation-based thermal resistances, entransy dissipation numbers and entropy generation numbers as shown in Figs. 5, 6, 7, 8, 9, 10 and 11. These curves indicate: (1) maximum percentage decrements in the rate of heat transfer between flowing fluids (i.e., 48.075, 31.372 and 28.705\%) were found for $\mathrm{Cu}$-water, steel-ammonia and $\mathrm{Al}-$ water combinations as inner pipe materials and cold fluids when surface roughnesses were highest but maximum percentage increment (i.e., $114.162 \%)$ achieved with $\mathrm{Cu}$-water combination when
Table 2 Outlet temperatures of four meshes

\begin{tabular}{llllll}
\hline Meshes & $\begin{array}{l}\text { Iteration } \\
\text { converged }\end{array}$ & $\begin{array}{l}\text { Inlet temperature } \\
\text { of cold fluid (K) }\end{array}$ & $\begin{array}{l}\text { Inlet temperature } \\
\text { of hot fluid (K) }\end{array}$ & $\begin{array}{l}\text { Outlet temperature } \\
\text { of cold fluid (K) }\end{array}$ & $\begin{array}{l}\text { Outlet tempera- } \\
\text { ture of hot fluid } \\
(\mathrm{K})\end{array}$ \\
\hline 1 & 191 & 300.0 & 350.0 & 308.450 & 342.027 \\
2 & 140 & 300.0 & 350.0 & 308.333 & 342.135 \\
3 & 205 & 300.0 & 350.0 & 308.216 & 342.242 \\
\hline
\end{tabular}


Fig. 3 Temperature contours for steel, aluminum and copper at conditions (a)

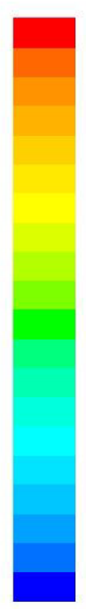

$3.50 \mathrm{e}+02$

$3.47 e+02$

$3.45 e+02$

$3.42 e+02$

$3.40 e+02$

$3.37 e+02$

$3.35 \mathrm{e}+02$

$3.32 \theta+02$

$3.30 \theta+02$

$3.27 e+02$

$3.25 \mathrm{e}+02$

$3.22 e+02$

$3.20 \theta+02$

$3.17 e+02$

$3.15 e+02$

$3.12 \mathrm{e}+02$

$3.10 e+02$

$3.07 \mathrm{e}+02$

$3.05 e+02$

$3.02 e+02$

$3.00 e+02$
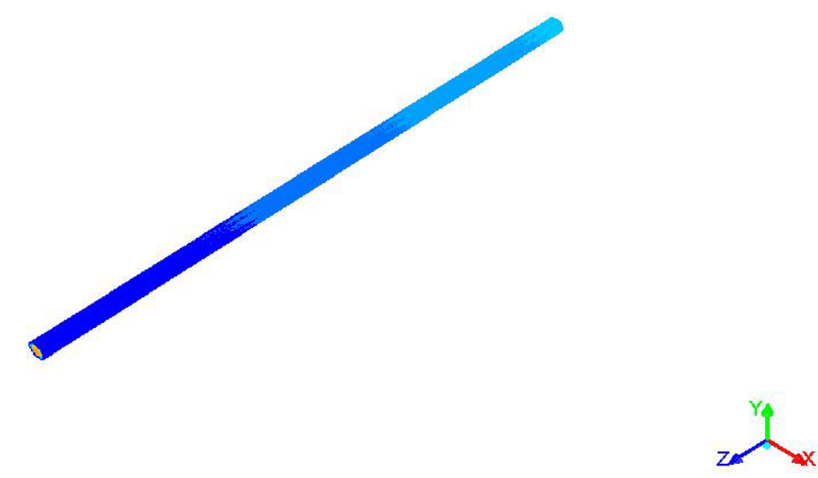

Contours of Static Temperature (k)

Aug 16, 2018 ANSYS Fluent 15.0 (3d, dp, pbns, ske)

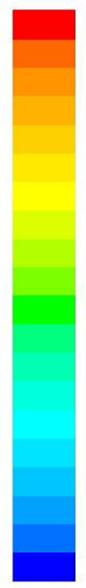

$3.50 e+02$

$3.47 e+02$

$3.45 e+02$

$3.42 \mathrm{e}+02$

$3.40 \mathrm{e}+02$

$3.37 e+02$

$3.35 e+02$

$3.32 \mathrm{e}+02$

$3.300+02$

$3.27 e+02$

$3.25 e+02$

$3.22 e+02$

$3.20 e+02$

$3.17 \mathrm{e}+02$

$3.15 e+02$

$3.12 e+02$

$3.10 e+02$

$3.07 \mathrm{e}+02$

$3.05 e+02$

$3.02 e+02$

$3.00 e+02$
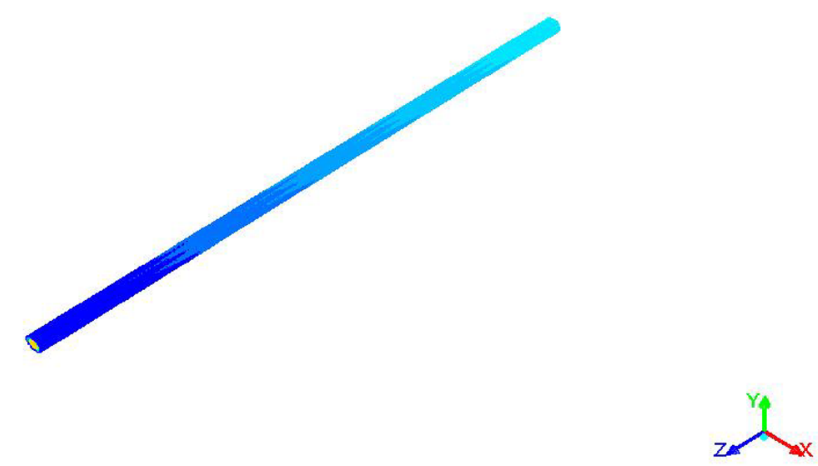

Contours of Static Temperature (k)

Aug 16, 2018 ANSYS Fluent 15.0 (3d, dp, pbns, ske)

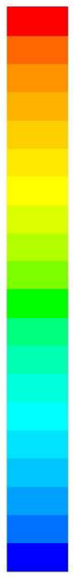

$3.50 e+02$

$3.47 \mathrm{e}+02$

$3.45 e+02$

$3.42 \mathrm{e}+02$

$3.40 e+02$

$3.37 e+02$

3. $35 \mathrm{e}+02$

$3.32 \mathrm{e}+02$

3. $30 e+02$

3. $27 e+02$

$3.25 e+02$

3. $22 \mathrm{e}+02$

$3.20 e+02$

$3.17 e+02$

$3.15 \mathrm{e}+02$

$3.12 e+02$

$3.10 \theta+02$

$3.07 \mathrm{e}+02$

$3.05 e+02$

$3.02 e+02$

$3.00 \mathrm{e}+02$

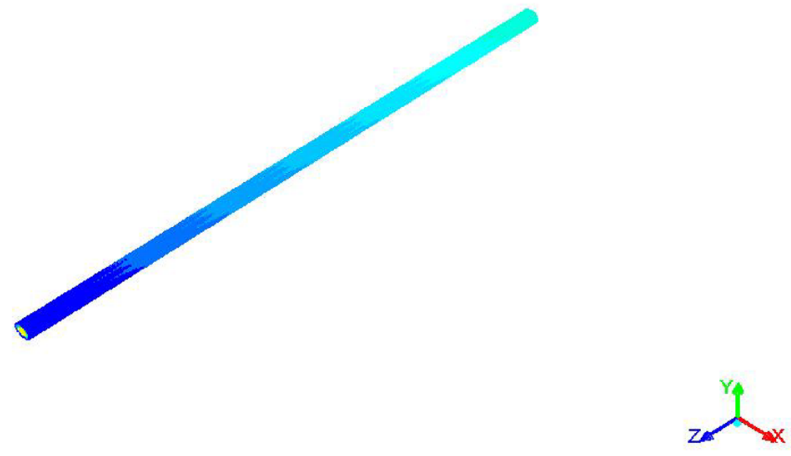

Contours of Static Temperature (k)

Aug 16, 2018 ANSYS Fluent 15.0 (3d, dp, pbns, ske) 
Fig. 4 Temperature contours for steel, aluminum and copper at conditions (b)

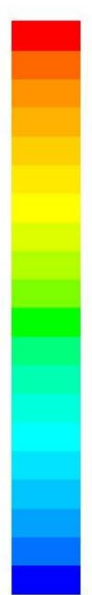

$3.00 e+02$

$2.96 e+02$

$2.91 e+02$

$2.86 e+02$

$2.82 e+02$

$2.77 e+02$

$2.73 e+02$

$268 e+02$

$2.64 e+02$

$2.59 e+02$

$2.55 \mathrm{e}+02$

$2.50 \theta+02$

$2.46 e+02$

$2.410+02$

$2.37 e+02$

$2.32 e+02$

$2.28 e+02$

$2.23 e+02$

$2.23 e+02$

$1.140+02$

$2.10 e+02$
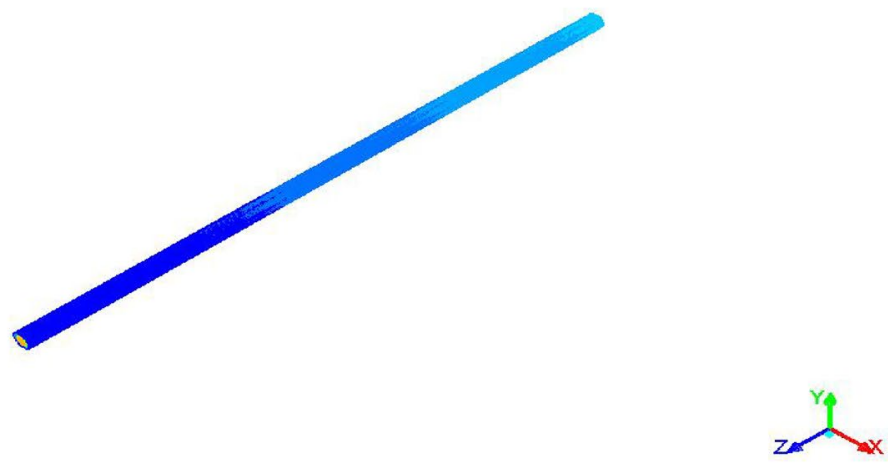

Contours of Static Temperature (k)

Aug 16, 2018 ANSYS Fluent 15.0 (3d, dp, pbns, ske)

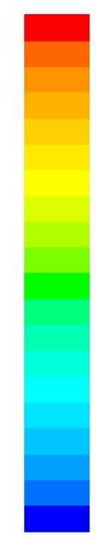

$3.00 \theta+02$

$1.05+0.02$

$2.91 e+02$

$2.86 e+02$

$2.82 \theta+02$

$2.77 \theta+02$

$2.73 \mathrm{e}+02$

$2.68 \mathrm{e}+02$

$2.64 \theta+02$

$2.59 e+02$

$2.55 e+02$

$2.50 \theta+02$

$2.46 \ominus+02$

$2.410+02$

$2.37 \mathrm{e}+02$

$2.32 e+02$

(1)

$2.23 e+02$

$2.19 \theta+02$

$2.14 \theta+02$
$2.10 \theta+02$
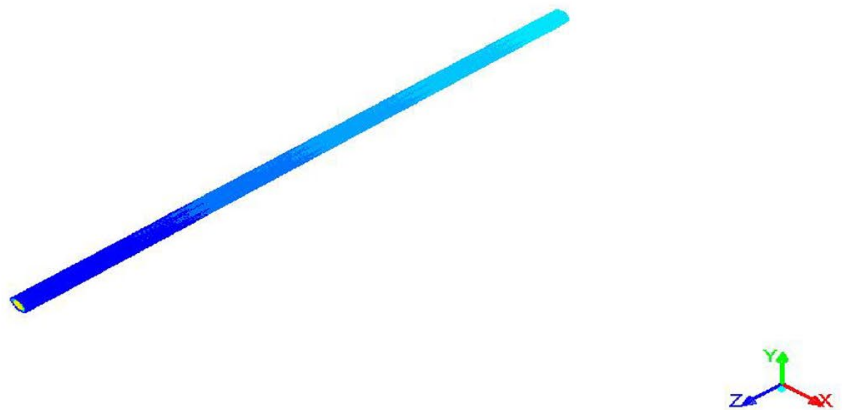

Contours of Static Temperature (k)

Aug 01, 2018

ANSYS Fluent $15.0(3 d, d p$

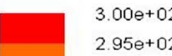

$2.95 e+02$

$2.86 \mathrm{e}+02$

$2.82 \theta+02$

$2.77 \theta+02$

$2.73 e+02$

$2.68 \mathrm{e}+02$

$2.64 e+02$

$2.59 \ominus+02$

$2.55 e+02$

$2.50 \theta+02$

$2.46 e+02$

$2.41 \theta+02$

$2.37 \mathrm{e}+02$

$2.32 e+02$

$2.28 \mathrm{e}+02$

$2.23 \mathrm{e}+02$

2. $19 \mathrm{e}+02$

$2.14 \mathrm{e}+02$

$210 e+02$

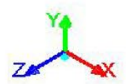

Contours of Static Temperature (k) Aug 14, 2018
ANSYS Fluent 15.0 (3d, dp, pbns, ske) 
Table 3 Results with steel pipe and change in pipe's roughness with different cold fluids

Table 4 Results with aluminum pipe and change in pipe's roughness with different cold fluids

Table 5 Results with copper pipe and change in pipe's roughness with different cold fluids

Table 6 Entropy, exergy and entransy analyses for water as hot and cold fluids

\begin{tabular}{|c|c|c|c|c|c|c|c|}
\hline \multirow[t]{2}{*}{ Inner pipe material } & \multirow[t]{2}{*}{ Cold fluid } & \multirow[t]{2}{*}{ Roughness } & \multicolumn{2}{|c|}{$\begin{array}{l}\text { Inlet temperature } \\
(\mathrm{K})\end{array}$} & \multicolumn{2}{|c|}{$\begin{array}{l}\text { Outlet temperature } \\
\text { (K) }\end{array}$} & \multirow[t]{2}{*}{$\begin{array}{l}\text { Rate of heat } \\
\text { transfer }(\mathrm{kW})\end{array}$} \\
\hline & & & Cold fluid & Hot fluid & Cold fluid & Hot fluid & \\
\hline \multirow[t]{6}{*}{ Steel } & \multirow[t]{3}{*}{ Water } & 0.0 & 300 & 350 & 308.450 & 342.027 & 2.669 \\
\hline & & 0.2 & 300 & 350 & 308.333 & 342.135 & 2.633 \\
\hline & & 0.4 & 300 & 350 & 308.216 & 342.242 & 2.597 \\
\hline & \multirow[t]{3}{*}{ Ammonia } & 0.0 & 210 & 300 & 232.288 & 275.458 & 9.314 \\
\hline & & 0.2 & 210 & 300 & 228.922 & 279.380 & 7.825 \\
\hline & & 0.4 & 210 & 300 & 225.663 & 283.156 & 6.392 \\
\hline
\end{tabular}

\begin{tabular}{|c|c|c|c|c|c|c|c|}
\hline \multirow[t]{2}{*}{ Inner pipe material } & \multirow[t]{2}{*}{ Cold fluid } & \multirow[t]{2}{*}{ Roughness } & \multicolumn{2}{|c|}{$\begin{array}{l}\text { Inlet temperature } \\
(\mathrm{K})\end{array}$} & \multicolumn{2}{|c|}{$\begin{array}{l}\text { Outlet temperature } \\
\text { (K) }\end{array}$} & \multirow[t]{2}{*}{$\begin{array}{l}\text { Rate of heat } \\
\text { transfer (kW) }\end{array}$} \\
\hline & & & Cold fluid & Hot fluid & Cold fluid & Hot fluid & \\
\hline \multirow[t]{6}{*}{ Al } & \multirow[t]{3}{*}{ Water } & 0.0 & 300 & 350 & 312.940 & 337.566 & 4.163 \\
\hline & & 0.02 & 300 & 350 & 310.812 & 339.629 & 3.473 \\
\hline & & 0.04 & 300 & 350 & 308.964 & 341.136 & 2.968 \\
\hline & \multirow[t]{3}{*}{ Ammonia } & 0.0 & 210 & 300 & 232.813 & 274.991 & 9.491 \\
\hline & & 0.02 & 210 & 300 & 230.656 & 277.403 & 8.576 \\
\hline & & 0.04 & 210 & 300 & 229.455 & 278.050 & 8.330 \\
\hline
\end{tabular}

\begin{tabular}{|c|c|c|c|c|c|c|c|}
\hline \multirow[t]{2}{*}{ Inner pipe material } & \multirow[t]{2}{*}{ Cold fluid } & \multirow[t]{2}{*}{ Roughness } & \multicolumn{2}{|c|}{$\begin{array}{l}\text { Inlet temperature } \\
(\mathrm{K})\end{array}$} & \multicolumn{2}{|c|}{$\begin{array}{l}\text { Outlet temperature } \\
\text { (K) }\end{array}$} & \multirow[t]{2}{*}{$\begin{array}{l}\text { Rate of heat } \\
\text { transfer (kW) }\end{array}$} \\
\hline & & & Cold fluid & Hot fluid & Cold fluid & Hot fluid & \\
\hline \multirow[t]{6}{*}{$\mathrm{Cu}$} & \multirow[t]{3}{*}{ Water } & 0.0 & 300 & 350 & 317.610 & 332.929 & 5.716 \\
\hline & & 0.015 & 300 & 350 & 311.402 & 338.809 & 3.747 \\
\hline & & 0.03 & 300 & 350 & 308.889 & 340.136 & 3.266 \\
\hline & \multirow[t]{3}{*}{ Ammonia } & 0.0 & 210 & 300 & 235.841 & 266.021 & 12.895 \\
\hline & & 0.015 & 210 & 300 & 233.619 & 270.014 & 11.380 \\
\hline & & 0.03 & 210 & 300 & 232.035 & 272.768 & 10.335 \\
\hline
\end{tabular}

\begin{tabular}{lllllllll}
\hline $\begin{array}{l}\text { Inner pipe } \\
\text { material }\end{array}$ & Pipe roughness & $d S_{\text {gen }}(\mathrm{kW} / \mathrm{K})$ & $\Psi_{\text {des }}(\mathrm{kW})$ & $G_{d}(\mathrm{~kW}-\mathrm{K})$ & $R_{\mathrm{d}}(\mathrm{K} / \mathrm{kW})$ & $E D N$ & $\varepsilon$ & $N_{\text {eg }}$ \\
\hline Steel & 0.0 & 0.00158 & 5.690 & 62.858 & 8.819 & 0.470 & 0.160 & 4.737 \\
& 0.2 & 0.00156 & 5.658 & 62.618 & 9.027 & 0.475 & 0.157 & 4.672 \\
& 0.4 & 0.00154 & 5.624 & 62.370 & 9.242 & 0.480 & 0.155 & 4.607 \\
$\mathrm{Al}$ & 0.0 & 0.00202 & 3.846 & 103.321 & 5.959 & 0.496 & 0.248 & 6.060 \\
& 0.02 & 0.00178 & 4.037 & 91.747 & 7.606 & 0.528 & 0.207 & 5.326 \\
& 0.04 & 0.00126 & 1.099 & 111.703 & 12.678 & 0.752 & 0.177 & 3.791 \\
$\mathrm{Cu}$ & 0.0 & 0.00235 & 2.948 & 130.853 & 4.004 & 0.457 & 0.341 & 7.041 \\
& 0.015 & 0.00161 & 1.809 & 123.408 & 8.786 & 0.658 & 0.223 & 4.806 \\
& 0.03 & 0.00118 & 0.280 & 119.492 & 13.556 & 0.804 & 0.177 & 3.549 \\
\hline
\end{tabular}

surface was smooth. (2) Maximum percentage changes for entropy generation, exergy destruction, entransy dissipation, entransy dissipation-based thermal resistance, entransy dissipation number, effectiveness and entropy generation number were found $(2.531,1.159,0.776,4.796$, $2.127,3.125$ and $2.744 \%$, respectively) for steel-water, 
Table 7 Entropy, exergy and entransy analyses for water as hot and ammonia as cold fluids

\begin{tabular}{lllllllll}
\hline $\begin{array}{l}\text { Inner pipe } \\
\text { material }\end{array}$ & Pipe roughness & $d S_{\text {gen }}(\mathrm{kW} / \mathrm{K})$ & $\Psi_{\text {des }}(\mathrm{kW})$ & $G_{d}(\mathrm{~kW}-\mathrm{K})$ & $R_{d}(\mathrm{~K} / \mathrm{kW})$ & $E D N$ & $\varepsilon$ & $N_{\text {eg }}$ \\
\hline Steel & 0.0 & 0.00970 & 31.654 & 494.056 & 7.314 & 0.667 & 0.272 & 2.897 \\
& 0.2 & 0.00889 & 30.473 & 424.252 & 8.897 & 0.682 & 0.230 & 2.657 \\
& 0.4 & 0.00795 & 29.248 & 349.687 & 10.991 & 0.688 & 0.187 & 2.374 \\
$\mathrm{Al}$ & 0.0 & 0.00999 & 32.371 & 490.717 & 6.996 & 0.651 & 0.277 & 2.983 \\
& 0.02 & 0.00938 & 31.260 & 457.361 & 7.987 & 0.671 & 0.251 & 2.801 \\
& 0.04 & 0.00818 & 27.597 & 502.084 & 9.292 & 0.758 & 0.243 & 2.443 \\
$\mathrm{Cu}$ & 0.0 & 0.00378 & 17.619 & 1034.50 & 7.986 & 1.009 & 0.377 & 1.131 \\
& 0.015 & 0.00518 & 19.447 & 873.617 & 8.664 & 0.966 & 0.333 & 1.548 \\
& 0.03 & 0.00600 & 20.904 & 763.242 & 9.177 & 0.929 & 0.302 & 1.792 \\
\hline
\end{tabular}

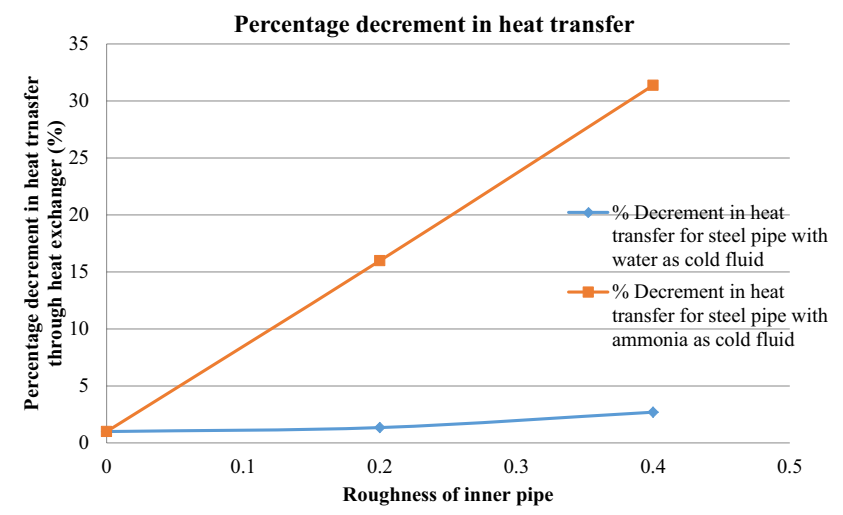

Fig. 5 Percentage decrement in heat transfer with steel pipe at different roughnesses
(18.041, 7.6, 29.221, 50.273, 3.148, 31.25 and $18.053 \%$, respectively) for steel-ammonia, $(37.623,71.424,8.112$, $112.753,51.612,28.629$ and $37.442 \%$, respectively) for Al-water, $(18.118,14.747,2.316,32.818,16.436,12.274$ and $18.102 \%$, respectively) for Al-ammonia, $(49.787,90.502$, $8.682,238.561,75.93,48.093$ and $49.595 \%$, respectively) for $\mathrm{Cu}$-water and $(58.73,18.644,26.221,14.913,7.928$, 19.893 and $58.443 \%$, respectively) for Cu-ammonia combinations at highest surface roughness, but comparatively less percentage changes for these parameters were found $(1.265,0.562,0.381,2.358,1.063,1.875$ and $1.372 \%$, respectively) for steel-water, $(8.35,3.73,14.128,21.643$, $2.248,15.441$ and $8.284 \%$, respectively) for steel-ammonia, $(11.881,4.966,11.201,27.638,6.451,16.532$ and $12.112 \%$,

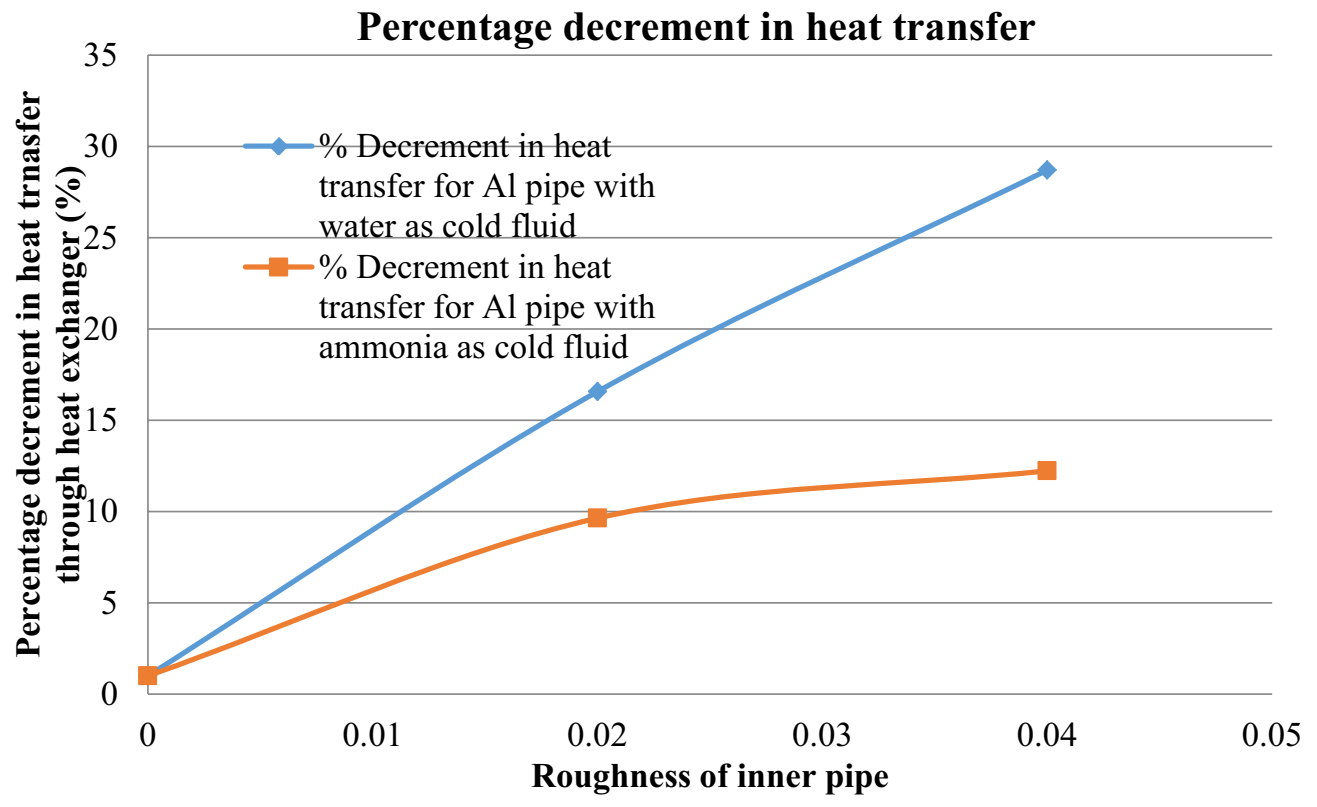

Fig. 6 Percentage decrement in heat transfer with aluminum pipe at different roughnesses 


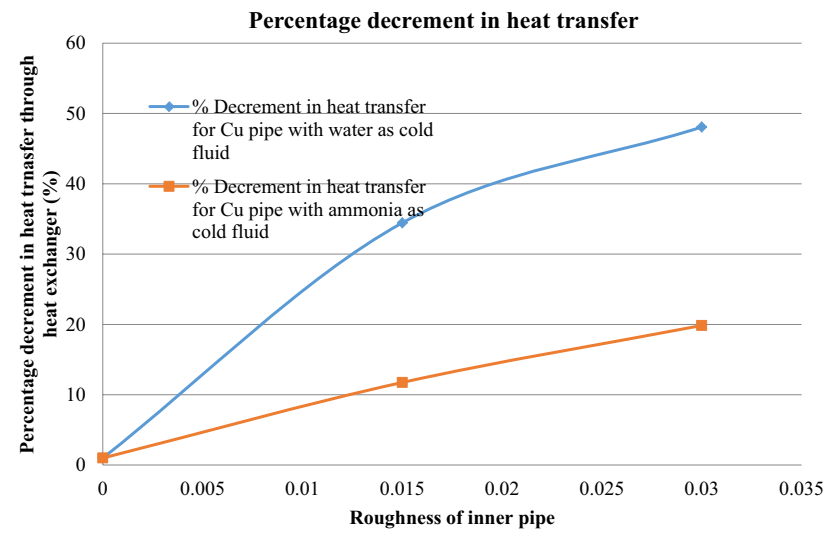

Fig. 7 Percentage decrement in heat transfer with copper pipe at different roughnesses

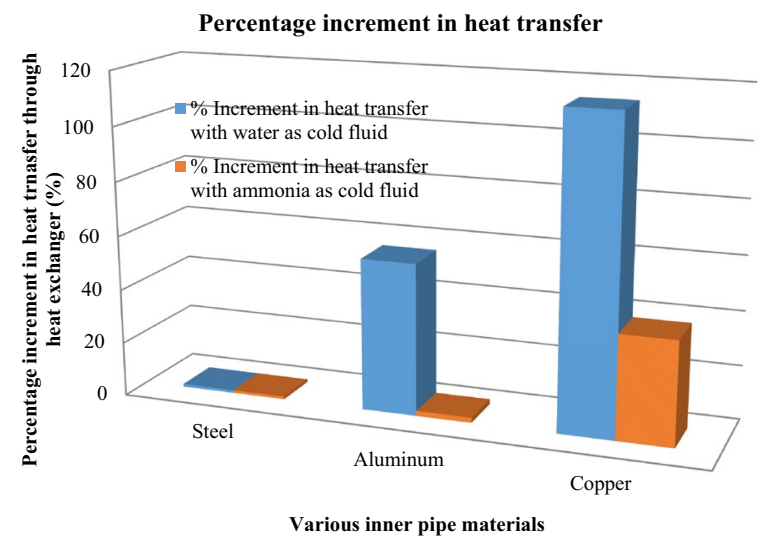

Fig. 8 Percentage increment in heat transfer with different inner pipe materials

respectively) for Al-water, $(6.106,3.432,6.797,14.165$, $3.072,9.386$ and $6.101 \%$, respectively) for Al-ammonia, $(31.489,38.636,5.689,119.43,43.982,34.604$ and $31.742 \%$, respectively) for Cu-water and $(37.037,10.375$, $15.551,8.489,4.261,11.671$ and $36.87 \%$, respectively) for $\mathrm{Cu}$-ammonia combinations for smoother surfaces of inner pipes of double-pipe counter flow heat exchanger.

Computer software has also been developed in this research work called effect of surface roughness on the performance of heat exchanger (ESRPHEx) as shown in Fig. 12, and this computer software is useful to eliminate human errors during mathematical calculations and also helpful to reduce time consumption during the analyses [30].

\section{Conclusion}

In this research work, comparative analyses of heat exchanger with steel, aluminum and copper as inner pipe materials and with water and ammonia as cold fluids have been done and observed that the maximum amount of heat transfer between flowing fluids and effectiveness of heat exchanger is $12.895 \mathrm{~kW}$ and 0.377 , which have been found when copper was used as inner pipe with smooth surface finish and ammonia as cold fluid. It has also been concluded that the following conditions are required for best performance from a heat exchanger: entropy generation rate, entropy generation number, exergy destruction rate, entransy dissipation rate, entransy dissipation-based thermal resistance and entransy dissipation number should be minimum. So, minimum rate of entropy generation is $0.00118 \mathrm{~kW} / \mathrm{K}$, entropy generation number is 1.131 , exergy destruction rate is $0.280 \mathrm{~kW}$, entransy dissipationbased thermal resistance is $4.004 \mathrm{~K} / \mathrm{kW}$, and entransy dissipation number is 0.457 which have been found with copper pipe. Maximum percentage increment has been found when copper was used as inner pipe material with smooth surface. It has also been observed that when water was used as cold fluid, the percentage changes in entropy generation, exergy destruction, entransy dissipation, entransy dissipation-based thermal resistance, entransy dissipation number, effectiveness and entropy generation number increase with thermal conductivity of inner pipe, and percentage changes in these parameters were less with ammonia as compared to water at same operating conditions. After analyses, high heat capacity of fluid (i.e., ammonia as cold fluid) and high conductive material (copper as inner pipe) with smooth surface have been recommended to get best performance from heat exchanger. 
Fig. 9 a, b Percentage change in properties with steel pipe at different roughnesses: a water and $\mathbf{b}$ ammonia as cold fluids
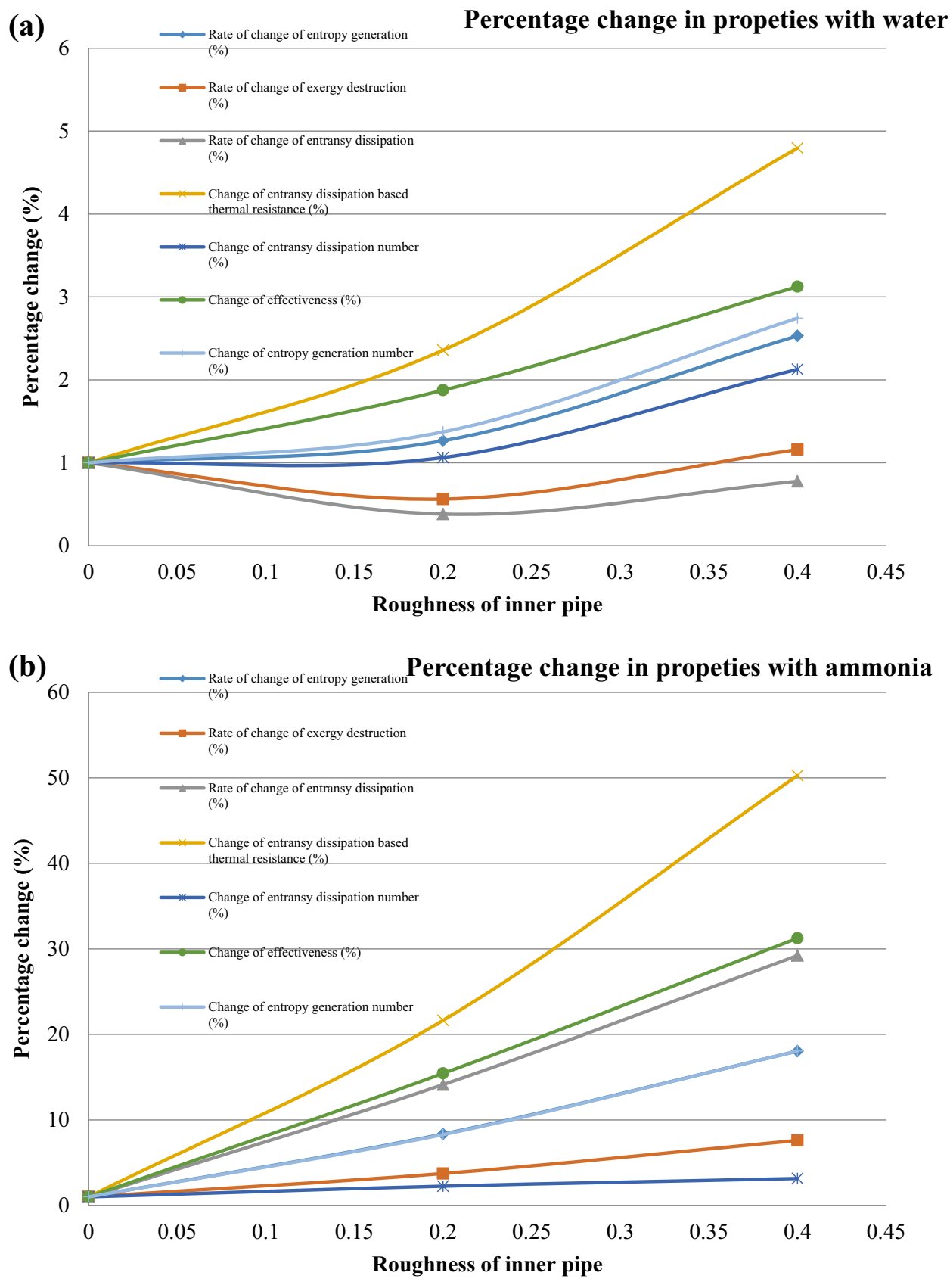
Fig. 10 a, b Percentage change in properties with aluminum pipe at different roughnesses: a water and $\mathbf{b}$ ammonia as cold fluids

\section{(a)}

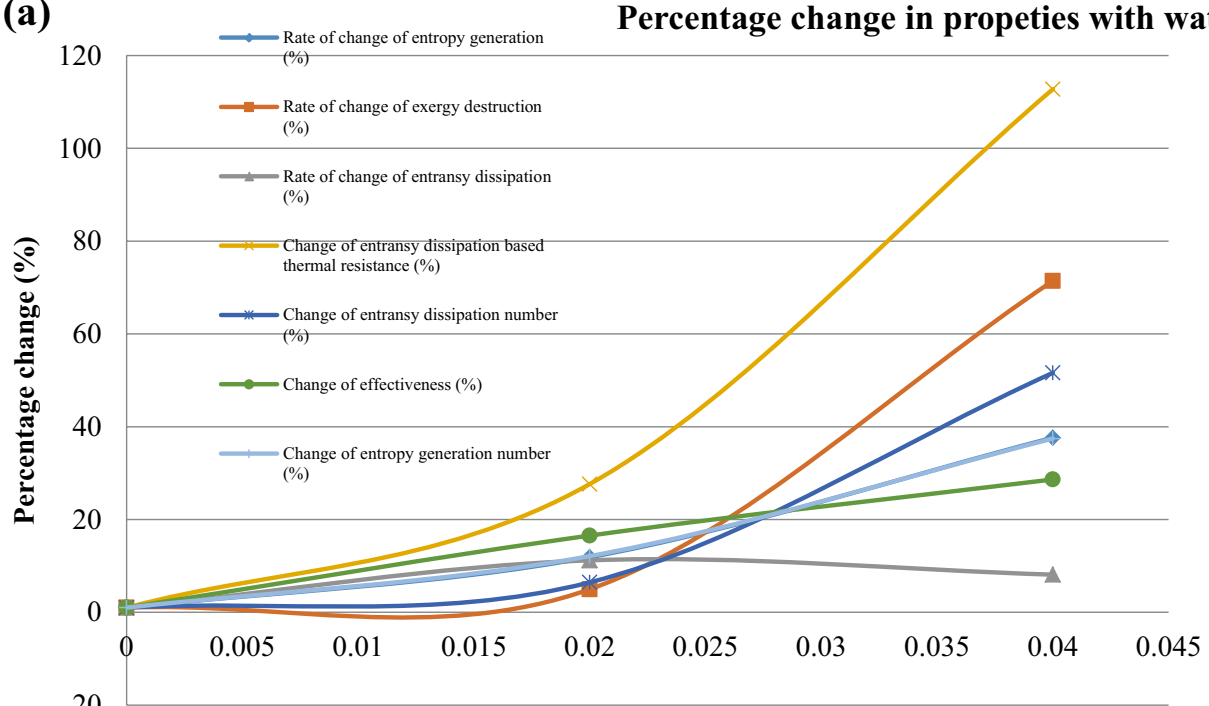

Roughness of inner pipe

(b)

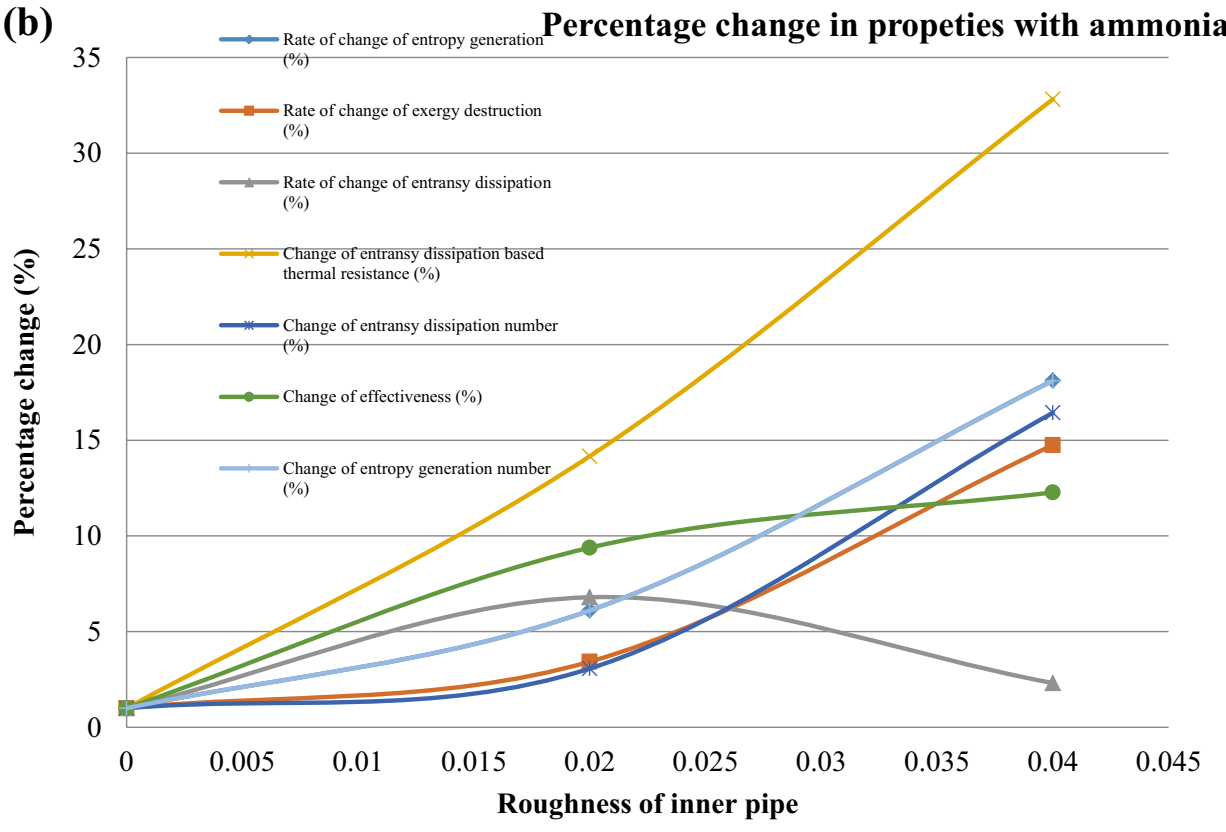


Fig. 11 a, b Percentage change in properties with copper pipe at different roughnesses: a water and $\mathbf{b}$ ammonia as cold fluids

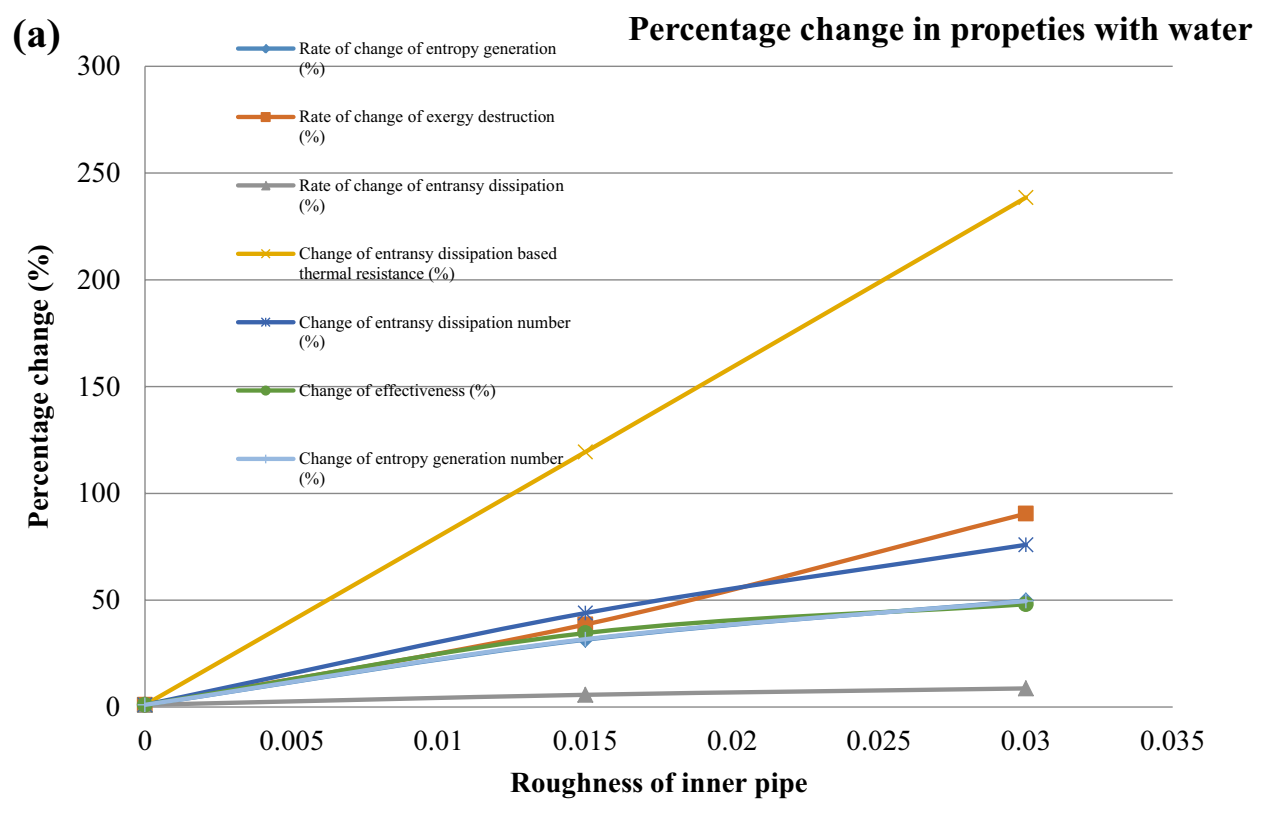

(b) 70 Rate of change of entropy generation Percentage change in propeties with ammonia

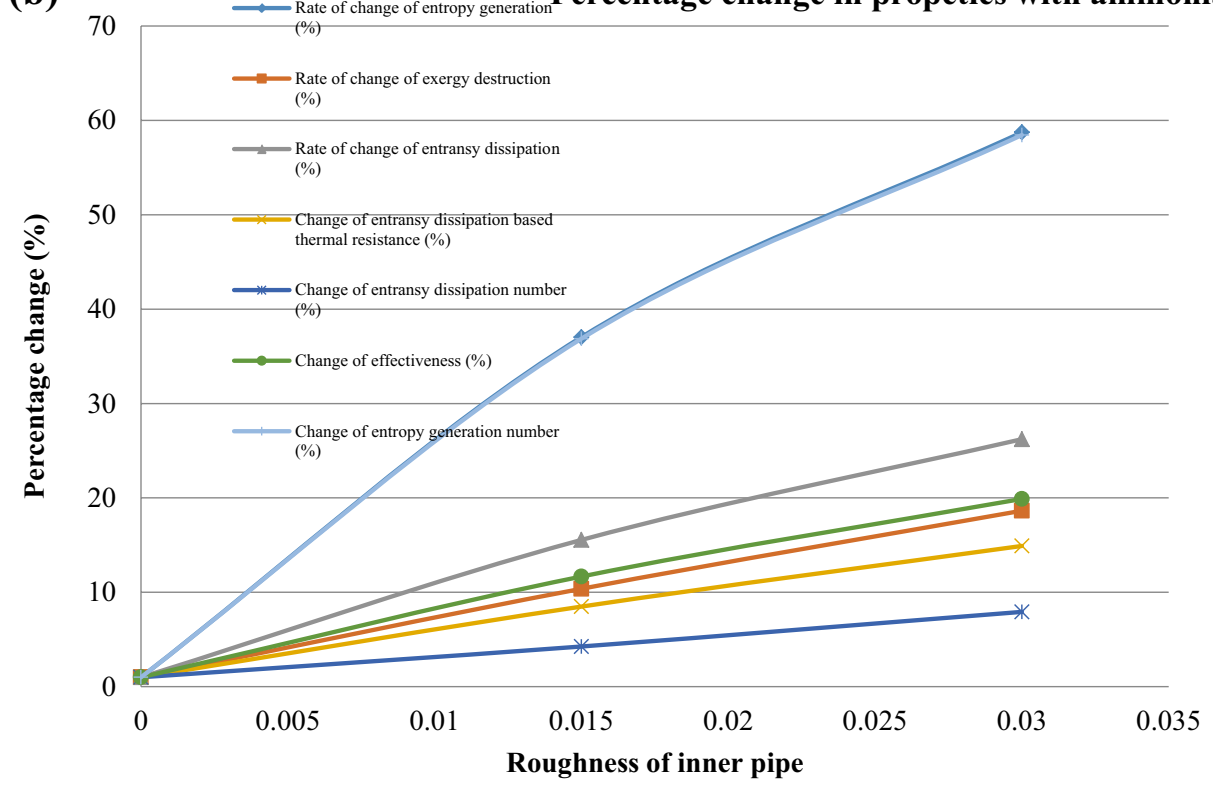




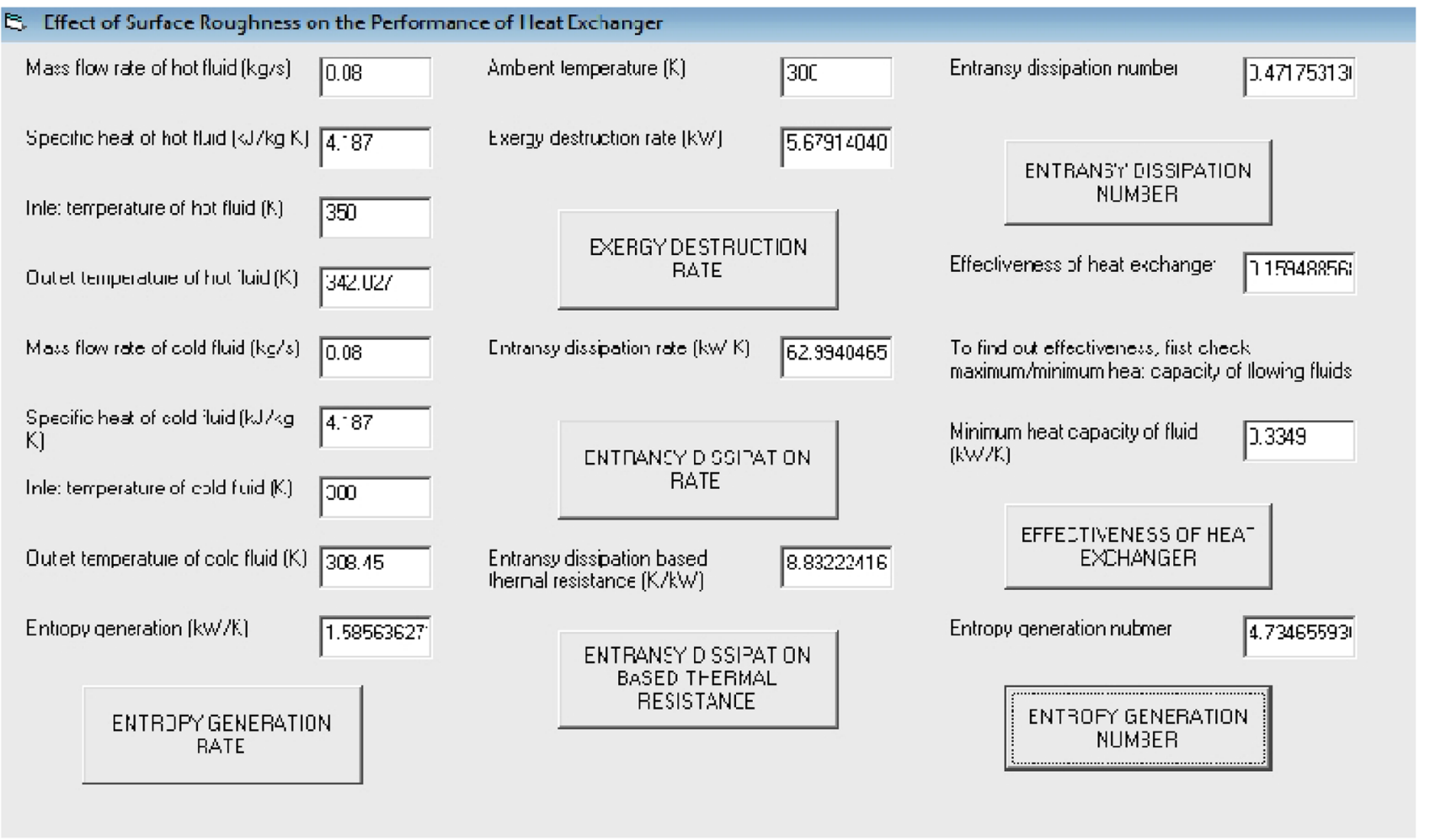

Fig. 12 Developed computer software for performance analyses

Acknowledgements This research work is done by research scholar at Sushila Devi Bansal College of Technology, Indore, Madhya Pradesh, India.

\section{Compliance with ethical standards}

Conflict of interest The authors declare that they have no conflict of interest.

\section{References}

1. Cengel AY (2003) Heat transfer: a practical approach. Tata McGraw-Hill Publication, New York

2. Holman JP (2009) Heat transfer. Tata McGraw-Hill Publications, New York

3. Lienhard HJ (2008) A heat transfer text book. Phlogiston Press Cambridge, Massachusetts

4. Whitaker S (1983) Fundamental principles of heat transfer. Robert E. Krieger Publishing Company, Inc.Krieger Drivemalabar, Florida

5. Pathak R, Geete A (2019) Thermal performance analyses of concentric pipe counter flow heat exchanger at different operating conditions by CFD. $i$-Manager's J Mech Eng

6. Farshad FF, Rieke RR (2006) Surface-roughness design values for modern pipes. SPE Drilling \& Completion

7. Chen LG, Ma K, Ge YL, Sun FR (2017) Minimum entropy generation path for an irreversible light-driven engine with reacting system and linear phenomenological heat transfer law. Environ Eng Manag J 16(9):2035-2043

8. Chen LG, Wu C, Sun FR (1999) Finite time thermodynamic optimization or entropy generation minimization of energy systems. J Nonequilib Thermodyn 24(4):327-359

9. Chen LG, Xia SJ, Sun FR (2018) Entropy generation minimization for isothermal crystallization processes with a generalized mass diffusion law. Int J Heat Mass Transf 116:1-8

10. Chen LG, Yang AB, Xie ZH, Feng HJ, Sun FR (2017) Constructal entropy generation rate minimization for cylindrical pin-fin heat sinks. Int J Therm Sci 111:168-174

11. Chen LG, Zhang L, Xia SJ, Sun FR (2018) Entropy generation minimization for hydrogenation of $\mathrm{CO}_{2}$ to light olefins. Energy 147:187-196

12. Geete A (2017) Exergy, entransy and entransy based thermal resistance analyses of double pipe heat exchanger with different pipe materials. Heat Transf Res 48(18):1625-1636. https:// doi.org/10.1615/HeatTransRes.2017015641

13. Geete A (2015) Exergy, exergy destruction rate and exergy efficiency analysis of thermal power plants by computer software at various operating conditions. i-Manager's J Future Eng Technol 11(1):7-22

14. Geete A, Khandwawala AI (2014) Exergy analysis for $120 \mathrm{MW}$ thermal power plant with different inlet temperature conditions. Int J Res Eng Technol 2(1):21-30

15. Geete A, Khandwawala Al (2014) Exergy analysis for $120 \mathrm{MW}$ thermal power plant with different inlet pressure conditions and generate exergy outlet curves for different components. Asian Acad Res J Multidiscip 1(18):234-247

16. Ibrahim TI, Mohammed MK, Awad OI, Abdalla AN, Basrawi F, Mohammed MN, Najafi G, Mamat R (2018) A comprehensive 
review on the exergy analysis of combined cycle power plants. Renew Sustain Energy Rev 90:835-850

17. Chen LG (2012) Progress in entransy theory and its applications. Chin Sci Bull 57(34):4404-4426

18. Chen LG (2014) Progress in optimization of mass transfer processes based on mass entransy dissipation extremum principle. Sci China Technol Sci 57(12):2305-2327

19. Chen LG, Xiao QH, Feng HJ (2018) Constructal optimizations for heat and mass transfers based on the entransy dissipation extremum principle, performed at the Naval Univerisity of Engineering; a review. Entropy 20(1):74

20. Cheng XT, Liang XG (2013) Entransy, entransy dissipation and entransy loss for analyses of heat transfer and heat-work conversion processes. J Therm Sci Technol 8(2):337-352

21. Feng HJ, Chen LG, Liu X, Xie ZH, Sun FR (2016) Generalized constructal optimization of strip laminar cooling process based on entransy theory. Sci China Technol Sci 59(11):1687-1695

22. Feng HJ, Chen LG, Xie ZH, Sun FR (2016) Constructal entransy dissipation rate minimization of a rectangular body with nonuniform heat generation. Sci China Technol Sci 59(9):1352-1359

23. Feng HJ, Chen LG, Xie ZH (2018) Constructal optimizations for " + " shaped high conductivity channels based on entransy dissipation rate minimization. Int J Heat Mass Transf 119:640-646
24. Guo ZY, Zhu HY, Liang XG (2007) Entransy-a physical quantity describing heat transfer ability. Int J Heat Mass Transf 50:2545-2556

25. Wang C, Zhu Y (2018) Entransy analysis on boiler air pre-heater with multi-stage LHS unit. Appl Therm Eng 130:1139-1146

26. Xia SJ, Chen LG, Sun FR (2016) Optimization of equimolar reverse constant- temperature mass-diffusion process for minimum entransy dissipation. Sci China Technol Sci 59(12):1867-1873

27. Xia SJ, Chen LG, Xie ZH, Sun FR (2016) Entransy dissipation minimization for generalized heat exchange process. Sci China Technol Sci 59(10):1507-1516

28. Guo JF, Cheng L, Xu MT (2009) Entransy dissipation number and its application to heat exchanger performance evaluation. Chin Sci Bull 54(15):2708-2713

29. Bejan A (1982) Entropy generation through heat and fluid flow. Wiley, New York

30. Holzner S (2009) Visual Basic 6.0 programming black book. Dreamtech Press Publication, New Delhi

Publisher's Note Springer Nature remains neutral with regard to jurisdictional claims in published maps and institutional affiliations. 